\title{
Why Do Green Parties Emerge?
}

The British and German Greens in Comparative Perspective

\author{
Mathieu Petithomme \\ Institut d'Etudes Politiques de Paris \\ petithommemathieu@yahoo.fr
}

The emergence of Green parties has long been explained by the development of post-materialist values in advanced democracies. This article takes a somewhat different perspective, by reassessing the importance of institutional and strategic variables. The comparison between the British and the German cases reinforces the notion that post-materialist values might be considered as characteristics of the Green electorate more than independent variables of the emergence of Green parties. The paper shows that party systems financial and electoral characteristics can strongly influence the emergence of new parties. Similarly, the institutional features of a given system can multiply or reduce the possibilities of entry and of coalition-building of a new party. In the end, from a strategic viewpoint, the internal organisation of a given Green party and its position toward the questions of intra-party democracy, institutionalisation, and incorporation into the parliamentary game are determinant. Therefore, important institutional factors and strategic choices can explain the weaknesses of the Green party as well as the emergence and the conversion of the German Greens to classical political liberalism.

\section{Introduction}

The understanding of the root causes of the emergence of new parties in established democracies constitutes a core element in the comprehension of change in political competition structures. Indeed, the development of a new party implies a reorganisation of the electoral competition by limiting the votes of well-established parties. The emergence of a new party constitutes the result of a potential conflict within the political system between existing parties and the political group interested in constituting a new party. Before explaining more precisely the reasons for the emergence of Green parties in Germany and Great-Britain, it is necessary to shed some light on the theoretical debate within the literature on the emergence of new parties. In terms of perspective, the emergence of new parties has been analysed in relation to a given national context or following a comparative approach (Rosenstone et al. 1984; Hug 2001). This literature can also be classified following the type of emerging party considered, with research done on regionalist parties (De Winter \& Türsan 1998), on Christian-democratic parties (Kalyvas 1996), on right-wing parties (Harmel \& Sväsand 199: 501-23; Ignazi 1992: 3-34), or on left-wing libertarian/ecologist parties (Kitschelt 1998). In terms of explanatory factors, even if the empirical operationalisation of existing theories is sometimes partial, the emergence of new parties has been explained following (1) social, (2) institutional or (3) strategic variables. 
(1) The social approach argues that the emergence of new parties is intrinsically linked with the socio-economic mutations of a given society and the consequent transformation of individual values (Inglehart 1991: 11). The development of new social values would favour the electoral success of new parties promoting the politicisation of these new issues.

(2) In opposition, the institutional approach emphasizes that the probability for the emergence of new parties depends on the characteristics of political institutions and the existence of a favourable structure of opportunities for new party entry (Hug 2001: 11). The decision to get involved within the electoral competition would be affected by the costs of entry, the perceived benefits of the access to public office and the probability of receiving electoral support (Tavits 2006: 100).

(3) Finally, the theory of strategic entry highlights that the emergence of new parties might be related with elitist decisions to contest the existing electoral scene (Cox 1997). Following this paradigm inspired by rational-choice theory, political elites would enter within the process of electoral competition following three types of objectives: the desire to maximize their control on political positions, the willingness to influence the definition of public policies and the objective to maximize their electoral results, either for becoming a coalition partner of the government, or to access a blackmail position within the redefined political system (Storm \& Müller 1999: 5-9; Sartori 2005 [1976: 149). Following this third stream of explanatory variables, the emergence of new parties would be related to the strategy of interested political entrepreneurs.

\section{Post-industrial Society, Post-materialist Values and the Emergence of Green Parties}

Since the 1970s, western European party systems have experienced processes of change and reconfiguration. For instance, the relative decline of the militant-party type, the weakening of partisan identification, the tendencies of a higher degree of electoral volatility, the progression of "emotional", "affective" or "protest" voting and the increasing complexity of political competition resulting from the emergence of left-wing libertarian/ecologist or rightwing/authoritarian parties, have all contributed to party system change (Mair 1995: 40; Schmitt \& Holmberg 1995: 96). However, these dynamics are not directly connected with a weakening of the traditional functions of parties to aggregate popular demands and make public decisions. Nevertheless, they support the analysis of a growing crisis of political representation. In this context, the emergence of Green parties within established political systems will be assessed, testing the classic hypothesis which states that the structural socioeconomic mutations experienced by Western European democracies since the 1960s have favoured the development of new post-materialist values emphasizing political participation, power decentralization, individual self-realization, quality of life and environmental preoccupations (Inglehart 1991: 12). Theoretically, following this model, the progression of post-materialist values would represent an independent variable of the emergence of Green parties. In fact, following Inglehart's indicator, many South European countries like Portugal, Greece, Spain, and Italy can still be considered as "materialist" with a low degree of social identification for post-materialist values. "Green parties are also very weak or even inexistent

\footnotetext{
* The thesis of post-materialism developed by Ronald Inglehart defends that the growth of financial incomes and the relative absence of war leads to a shift in citizens attitudes, which become less
} 
within these countries, which would confirm a priori the theory linking the emergence of Green parties with post-materialist values and socio-economic changes.

However, an important critique of this model argues that the socio-economic transformations which characterize the post-industrial society have facilitated the development of two and not only one set of new systems of values, post-materialism on the one hand and neo-conservatism on the other hand (Ignazi 1992: 5). Furthermore, even if we admit to the development of post-materialist values, a direct link with the emergence of Green parties does not seem to exist. Indeed, how can the theory explain that two countries like Germany and Great-Britain present similar levels of social identification towards postmaterialist values (43\% PM-55\% M and 44\% PM-53\% M respectively), yet the emergence of Green parties is not constant between the two countries? Following Sartori's definition, Die Grünen can be considered as a significant party as it presents a "coalition potential", being involved in governmental decisions with the German SPD in 1998 for instance. Die Grünen has also "blackmail potential" within the German political system, because its positioning has forced other parties to realign themselves and ideologically renovate their programmes (Sartori 2005 [1976]: 148-49). However, the British Greens have never obtained significant electoral support and failed to apply sufficient social pressure to modify established parties tactics of competition and propose new themes to the political agenda. As a result, we will try to solve the puzzle of Green parties' emergence by looking at other explanatory variables in the German and British cases. The following argumentation reflects the analytical hypothesis which defends that the emergence of Green parties could be linked to institutional and strategic factors.

\section{The Institutional Context}

The first institutional factor which can influence the emergence of Green parties might be the access to public finance within a given party system. Indeed, the rules which define political parties financing can constrain in a decisive manner the formation and the limits of political competition. Secondly, the legal environment and the rules of electoral ballot exercise restrictions or opportunities for the emergence of new parties, the political associations tending "to adapt the form of their activities to the formal structures of power" (Panebianco 1988: 12; Armingeon 2002: 104). Finally, the understanding of state-party relationships in Germany and Great-Britain foster a third explicatory factor for the emergence or nonemergence of Green parties.

\subsection{The Financing of Political Parties and the Emergence of the Greens}

preoccupied with material welfare than by individual subjective welfare. The degree of post-

materialism is measured by the following question: «There is a lot of talk these days about what (OUR COUNTRY)'s goals should be for the next ten or fifteen years. On this card are listed some of the goals that different people say should be given top priority. Would you please say which one of them you, yourself, consider to be most important in the long run?»: (1) Maintaining order in the country; (2) Giving people more say in important Government decisions; (3) Fighting rising prices ; (4) Protecting freedom of speech. Following Inglehart, people who choose the second and the fourth items are postmaterialists and those who choose the first and the third items are materialists. Those who choose an item of each composed a mix group (Eurobarometer 64.2: 24). 
The Green Party and the Financial Constraints of a Two-party System

Important historical roots could explain that the British system of financing political parties has largely facilitated the stability of the two-party system and the alternation in power between the Labour and the Conservatives since the Second World War. Since its foundation, the Green Party has never been able to bypass the necessary percentage of electoral support for accessing public finance and parliamentary representation. As a result, the Green Party is over dependant on membership fees and individual donations. Legally, the Green Party is considered as a national confederation of local political associations, the House of Commons conditioning the access to public finance since 1975 to the share of two seats at the general elections or one seat and a minimum of 150,000 votes (Bogdanor 1984: 130). Political parties being not legally recognized by the law, the pluralist British system has the consequence to let third parties be highly dependent on their own resources, the necessity of self-financing becoming a major constrain of the political system in itself.

In fact, the access to public finance is restrained to parliamentary representation, limiting drastically the probability of the emergence of new parties, and establishing a clear differentiation between well-established and new parties. Moreover, the own independent ethic of the Green Party complicates its emergence, as its ideology is against donations from private enterprises and moral persons, in opposition to the Labour party which has always been linked with the Trade Unions and the Conservatives with business firms (Faucher 2003: 192). As a consequence, the scarce resources available reinforce a high cost of party formation for the British Greens, being regularly unable to present candidates in all the electoral circumscriptions on the one hand, and incapable of taking financial risks given the low probability of obtaining the reimbursement of electoral campaign expenditures afterwards (Bogdanor 1984: 134). Thus, the repertory of actions and the Greens electoral strategy become largely limited. Therefore, the political system favours the status quo between established parties (Webb \& Fisher 1999: 16-17).

\section{Die Grünen and the German Financing of Political Parties}

In Germany, the 1949 fundamental law limits constitutionally the public financing of political parties to the governmental process, that is to say, to the selection of political personnel (Poguntke 1994: 185). Only the electoral expenses can be reimbursed but not the general maintenance of a given political party. While the Flick scandal in the beginning of the 1980s has largely contributed to a fall in donations, the public funding of Bundestag parties has constantly progressed since the end of the Second World War. Public subventions already represented between 60 and $80 \%$ of the federal parties total incomes in the early 1990 s (Poguntke \& Boll 1992: 384). Since their first electoral victory in 1983 and their entry to the Bundestag, Die Grünen have benefited from this public financing, which has undeniably helped to consolidate the formation of the party (Poguntke 1994: 197).

Contrary to the British Greens who exclusively depend on their membership fees, in 1993, only $10 \%$ of Die Grünen total budget came from its members. In other words, the German system has played a permissive role in the progressive institutionalisation of the Greens. In the same way, after the Unification Treaty, the $3^{\text {rd }}$ October 1991 Law on Political Parties has given a high proportion of public finance for political parties, legitimizing the electoral strategy of the new social movements and reducing the costs of the formation of new 
political parties (Olivo 2001: 121). Finally, and in opposition with the British Greens, the Grünen have stimulated their own parliamentarians to redistribute a part of their incomes to some ecological funds in order to provide financial aid to the deepening of alternative projects (Poguntke 1993: 145). Benefiting of public subsidies at the federal level, this strategy of "politics from below" further reinforced the social anchorage of the party at the local level.

\subsection{Ballot Electoral Rules and Political Institutions}

\section{Great-Britain}

Parallel to the system of financing political parties, the British ballot electoral system might constitute one of the most constraining factors for the emergence of new parties. For general elections, the use of the uninominal one-round majority ballot, known as the electoral system of the "first-past-the-post", has the direct consequence to favour the already well-established parties. The impossibility for a second decisive round between government parties and the very low probability of victory of an emerging party at the first round almost always leads to a "utility-vote" from the electorate, to the detriment of new parties. In addition, the ballot creates a high disproportion between the number of votes and the number of seats obtained, encouraging the over-representation of the most popular party (Crewe 1993: 83). On a regional basis, this deviation from the proportionality of the parliamentary representation seems even more important (Dunleavy et al. 1994: 181). Accordingly, this facilitates governmental stability by enabling the winner to count on an absolute majority at the Commons and forms a strong government with the support of only one third of the electorate. The British ballot therefore constitutes a key factor in the low probability of the emergence of the Greens as an important third national party. Thus, the "Westminster system", intrinsically related with the British two-party system is a reflection of a conservative political culture, which favours bipolarisation, reinforces a dynamic of centripetal competition and sanctions extremism. Contrary to the Grüner, the political isolation created from an unfavourable ballot system may have contributed to the development of a peripheral culture within the British Greens and as a result, stimulated the triumph of the radical stream of the party (Douglas \& Wildasky 1983 208).

\section{Germany}

In Germany, important constitutional parameters have constrained political parties, such as the federal structure of government and the autonomy of political parties from their extraparliamentary organizations. These institutional factors have fostered the fragmentation of German political parties in federations of organisations within a system of multi-level governance constituted by the federal, the Länd and the local level. Consequently, the German federal system may have augmented the possibility for strategic entry of the German Greens into the political system, thereby creating a favourable political opportunity structure for emergence. Additionally, the proportional ballot with compensation used in Germany presents a dual advantage: it enables a representation of proximity of the electorate (each one having a MP in its circumscription), and at the same time, equally represents political forces (Martin 2000: 41). This system with a proportional finality gives two votes to the electorate and mixes a uninominal ballot (with one round for the designation of half of the MPs) with a list ballot in order to determine "the global proportion of seats that each party bypassing $5 \%$ - or obtaining more than three MPs at the uninominal ballot - has the right to" 
(Ibid. 2000: 41). The effects of majority created by the uninominal ballot are compensated by the election of half of the Bundestag MPs at the list ballot. The idea is to mix the supposed effects of the proportional and majority electoral system. Contrary to the British system the personality of the leader and the proximity with the electorate might play a more important role at the local level. Finally, the electoral ballot favours the development of a multiparty system, and reinforces the potential for new parties, like the German Greens, to emerge on the political scene.

\subsection{State-Parties Relations}

British Pluralism and the Emergence of the Greens

Even if Great-Britain is considered to be pluralist in regards to interest groups studies, in practice, the access to public resources is still largely controlled by the two major parties. For instance, only government parties can decide the beneficiaries of "quangos" (quasiautonomous non-governmental organisations) non-elective seats financed by the British state (Heywood 1994: 18). In spite of a historically pluralist character, British political power remains highly centralised, enabling governmental parties to benefit largely from their institutional connections even if the societal identification toward these mainstream parties declines. Within this "weak state with strong power", the concentration of resources at the government level limits the potential influence of emerging parties on policy-making (Burgi 1992: 402-16).Great-Britain remains a country with a very low degree of federalism and corporatism all the while maintaining a high degree of budgetary centralism (Grossman \& Saurugger 2006: 102-3).

Likewise, the limits of British pluralism can be illustrated by the access of parties to the Media. The British law prohibiting parties to buy a determined time-speech on the radio or on television, a mixed committee composed of the representatives of radio and television (BBC and Independent Broadcasting Authority), and of the representatives of the principal parties imposes informally the share of audiences for political parties campaigns. In the age of "the democracy of the public", the access to the Media seems to become a fundamental precondition for a possible electoral success. Yet, in Britain, the political programmes on the radio and the television are de facto divided between the three main political forces, marginalizing the Greens from the public debate (Manin 1995: 279). In the end, the British "pluralist system with corporatist tendencies" does not deepen the opportunities of the Green Party. Thus, it enhances the strategy of "conflictualisation" of the party and the vicious circle of "political marginalisation - political radicalisation" (Coxall 2001: 20; Kitschelt 1986; Tarrow 1995). The fact that the conventional relations between the British political institutions and the Green Party are not in favour of the latter reinforces the party strategy of external lobbying. Trying to mobilize the public through extra-parliamentary demonstrations and unconventional political means is the only way for the Greens to compensate the "institutional sclerosis" of the system, and be able to signal its political existence (Grossman \& Saurugger 2006: 87).

\section{Germany and the Parität more than Corporatism}

In Germany as in Great-Britain, mainstream political parties traditionally decide internally the nomination for political offices, public firms and bureaucratic promotions within the state apparatus. However, the fundamental divergence between the British and the German model 
is that in the German case, this repartition of offices does not only take place at the governmental level, but at all levels of the decision-making process (federal, Länd, local). Indeed, even if there is no consensus on the precise components in the German model, Germany would be an illustration of "organized pluralism". The country tends to fit in Lijphart "consensual democratic" model that is characterised by a system of more or less permanent negotiations between political forces at all levels of decision making (Lijphart 1999). Accordingly, the term "cooperative federalism" has been developed to comprehend the Parität, the close cooperation formulated between political parties on the most important debates within the multi-level of governance federal system (Wachendorfer-Schmidt 2000: 81).

Even if this system tends to favour established parties, it does not prevent minor parties to access public responsibilities and offices at the local or Länd level, facilitating the institutionalisation of new parties through their contact with real-life conditions. For instance, the German Greens first entered the government of different Länders during the 1980s before becoming a real national party (Poguntke \& Boll 1992: 330). In addition, the fact that the achievement of an absolute majority at the federal level has only been possible once since the Second World War (in part because the post-Nazi political system aimed to reduce the possibility of tyranny by a majority) has consequently fostered the process of coalitionbuilding, and therefore, has extended the blackmail potential of minor parties. Thus, Die Grünen became a governmental party in the aftermath of the 1998 general elections, creating a coalition with the SPD while the Greens obtained only $6.7 \%$ of the vote share.

\section{Questioning the Strategies of Green Political Actors}

For the ecologists, the choice to form a movement, and in some cases an autonomous political party has been motivated ambitions to create a new relation between civil society and political parties through the installation of participatory democracy (Icke 1990: 47). The Green theory argues that an active involvement of citizens in political life would balance the negative effects of "professionalisation" in political life. In that respect, following the inspiration of the new social movements, the Greens all over Europe would try to "do politics differently". Nevertheless, Green parties have presented different political strategies and multiple positions toward the crucial questions of institutionalisation, electoral competition and ideological renovation so as to become institutionalized political parties. In the next part, we will see how these strategic choices in the British and the German context have constrained the emergence of the Greens.

\subsection{The Green Party from Marginalisation to Radicalisation}

Intra-Party Democracy, a Vector of Electoral Success...

In terms of party institutionalisation, the Green Party has deliberately opted for a strategy of cultural revolution as an antecedent to an electoral revolution, by insisting on a necessary mutation of citizens' political mentality and values, even if it should be associated with an impossibility to conquer political power in the short term. Thus, the Green Party has preserved statutes which permit the survival of a weakly-structured and egalitarian movement reticent toward party institutionalisation. The resulting dynamic result of the permanent opposition between the realists and the fundamentalists has led to the victory of 
the latter, which are sceptical toward party hierarchies and social change through parliamentary means. As a result, intra-party decentralisation has been reinforced while the strategy of competition against other parties has become marginalised. For the Green Party, political renewal has to become a reality not only in reforming political institutions in the long term, but also through the realization of direct and intra-party democracy in the short term (Saward 1993: 71). In that sense, the centrifugal dynamic of competition of the Green Party has reduced the prospects for compromise and electoral coalitions with third parties. The Greens have been unable to transfer the ecological issue from the social to the political sphere.

Moreover, in order to avoid the control of political offices by an oligarchy of militants, the Green Party has institutionalised a system of rotation of the executive offices of the party every three years, prohibiting in the same way the accumulation of mandates. However, this also creates a regular shortage of experienced leaders. In terms of internal functions, the decision-making process is even more long and complicated now that the party tries to promote equal participation of all its members. Consequently, the willingness to promote intra-party democracy and to control the leadership has led the Greens to be incapable to react to external constrain and to develop a clear political message (Katz \& Mair 1994: 611). The executive decisions of the party must always be accepted $a$ priori and $a$ posteriori by the militants, which led reformists Sara Parkin, Jonathan Porritt and Paul Ekins to leave the party in 1992 (Faucher 2003: 218). In the end, the promotion of "collective leadership" and the rejection of all hierarchies might have diminished the possibility to transform the movement into a political instrument.

\section{...Or an Internal Response to the Failure of a Parliamentary Strategy?}

Accordingly, the fact to permit deliberation without limits deepen the risk that internal debates focus on the details of a text more than on important political and strategic issues. In trying to institutionalize social pluralism, the Green party has not been able to limit the perverse effects of direct democracy. The sovereignty of its members on the activities and the programme of the party, the sanctification of deliberation, the egalitarian participation and the willingness of absolute transparency constitute not only the democratic exemplarity of the Green Party, but also reinforce the barrier towards party institutionalisation and entry into the electoral competition. In spite of a strategic choice at the beginning of their existence to enter into the political system, the readiness of the Greens to take consensual decisions without leadership and to decentralise internal political power has created "a weak movement and a quasi-disappearance of the national structures", leading the Green Party to become a network of local groups more than a nationally coordinated political party (Faucher 2003: 206). In other words, its intransigent strategy has led the Green Party to occupy de facto the margins of the political system. The absence of decision-making responsibilities and political influence within the British political system has become a determinant influence on its internal ideological debate (Bennie et al. 1995: 236).

As a consequence, the Green Party decision to promote an extra-parliamentary strategy seems to be the result of the breakdown of its parliamentary strategy. Indeed, even if the Greens have focused on the elections and have tried to obtain seats since the beginning, their repeated electoral failures and the militants' sentiment of impotency have favoured the 
emergence of radical members within the party at the beginning of the 1990s. Then, the new political line of the party has become that of a politicisation of non-electoral activities, an enlargement of its political strategy to direct non-violent actions and the construction of networks of citizens and associations. The renewal of the party's repertory of action toward unconventional political means has been presented by the new militants as a multiplication of political opportunities allowing each citizen to get involved following his personal motivation (Rucht 1990: 159). It is true that more than $86.7 \%$ of the Green Party's members are also part of an association. This reinforces the idea of a multiple political engagement of British ecologists (Rüdig 1995: 238). Therefore, the debate for the Greens has been structured on the question of the strategic option of institutionalisation more than on the political positioning in relation to other political parties. Nevertheless, the rupture chosen in searching electoral coalitions to incarnate the confluence of social movements seems diametrically opposed with that of the German Greens, and does not appear to bring real success. In fact, the transition of the Greens toward unconventional forms of political participation shows its impotency in front of a multitude of factors, thereby reducing the probability of its emergence.

\subsection{Die Grünen: From a Citizen Movement towards a Reformist Political Party}

\section{The Institutionalization of Citizen Movements}

The paradigmatic process of institutionalisation of the German ecologist movement can be better illustrated by the ex-GDR citizen movement evolution. At the beginning of the 1980s, the GDR citizen movement had the objective to create a Gegenöffentlichkeit, a "counterpublic sphere", promoting democratic reform and the defence of human rights in the former GDR. This ideological platform will constitute the basis for the future synthesis between citizen movement and party structure around the reunified Greens Alliance 90/Die Grünen. Since 1988, more than 325 groups such as the "Initiative for Peace and Human Rights" (IPHR) created by Wolfgang Templin in January 1986, the movement Demokratie Jetz, "Democracy Now" (DN) created by Reinhard Lampe and the Neues Forum, the "New Forum" (NF), were insisting on the necessity to mobilize citizens for political change after decades of apathy and mass demobilization. Hence, this highly politicized political context might have favoured the dynamics of new party institutionalisation in response to renewed societal demands.

From the beginning, the citizen movements have tried to stimulate the creation of a public forum of deliberation, decentralised and promoting the Basisdemokratie, the democratisation of politics through the social basis (Olivo 2001: 92). Even if the strategy adopted was essentially extra-parliamentary, the citizen movements became progressively aware that party institutionalisation could permit them to play the role they wanted as a new intermediary between civil society and the state. Therefore, the initial electoral coalition Alliance 90 (IPHR, DN, NF) has also incorporated the social movements. In the aftermath of the $3^{\text {rd }}$ October 1990 unification Treaty, the process of coalition-building was fostered by the fusion of the Greens of the West and of the East in one single political party, Alliance 90/Die Grünen in May 1992. On that point, the strategy used differs radically from that of the British Greens. The Green critique of Parteiendemokratie, the "democracy of party" became suddenly obsolete with the institutionalisation, and only the ideal of participatory democracy constituted the specific feature of the new party in relation with established ones. The same 
trajectory as the British Greens has also existed in Germany, as the NF movement lead by Klaus Wolfram, Bärbel Bohlev and Ingrid Köppe has refused the incorporation in the parliamentary game and the creation of parliamentary coalitions, but in the German case, this strategy has been marginalised within the party (Markovits \& Gorski 1993: 257). In the end, the new party has adopted a more transversal or "catch-all" political position, less radical than the British Greens.

\section{The Progressive De-radicalisation of the German Political Ecology}

One could state that the force of the German Greens might have been the choice to operate a synthesis between a strategic entry within the electoral competition, and thus, a creation of classic party structure to make this strategy possible, and a preservation of the founding objectives of enhancing participatory politics and renewed political practices. Even if the strategy of power conquest requires a normalisation of party structures, the German Greens have tried to balance this effect by involving the social movements in their internal decisionmaking procedures, which are nevertheless subject to more hierarchical levels than in the British case. Trying to find an alternative to SPD's trade unions traditional support and to the CDU/CSU support from business circles, the Greens have tried to attract all social movements, making them count within the internal structure of the party in an innovative manner. This social anchorage has certainly facilitated to legitimize the party and encouraged its influence on the German political agenda (Kitschelt 1989: 226). In opposition with the British Greens, it is the realists which have conquered the internal battles, leading the ecological movement to "renounce a part of its original radicalism in order to obtain concrete proofs of the 'ecologisation' of society" (Faucher 2003: 23). In that sense, the dynamics of electoral competition has constrained the Greens, the necessity to conquer a legislative majority then becoming a prior objective towards the establishment of a new model of society.

In general, the emergence of the German Greens seems essentially related with the ideological evolution of the party from its 1980 Bundesprogramm to the programmatic renovation promoted by the Grundsatz of April 2002. Indeed, Die Grünen has evolved from a radical eco-socialism towards a political position which could be assimilated to that of classical political liberalism. For sure, these developments have not been possible without debates and controversies but it seems that the German Green Party has become a classical third party trying to exercise its blackmail potential and searching to enter in governmental coalitions. From the "limits to growth" rhetoric and the willingness to incarnate the new social movements of the period in the late 1970s, the Greens have been progressively incorporated into the political game, entering the Bundestag in 1983 with 5,3\% of the vote share and in 1987 with 8,3\% (Papadakis 1984: 48). The German Greens have successfully transformed ecology into a political concept and instrumental tool for politicizing new social issues and renewing the political agenda of established parties, trying to promote nowadays a radical democratic politics in favour of minorities, social justice and multiculturalism. Moving from an anti-establishment position toward an active role in the politicisation of the public agenda might have constituted a key factor in the emergence of the German Greens, reinforcing a realignment of part of the SPD electorate to the benefit of the Greens. After its $7,3 \%$ of the vote share in 1994, the Greens have become involved in a governmental coalition with the SPD in 1998, renouncing progressively to its founding objective to foster 
the "politics from below" towards a motivation to "reinforce the constitutional liberalism" (Bündnis 90/Die Grünen 2002: 7). The German Greens have moved from the defence of collective rights to that of individual rights, "the democratisation of democracy, conceived previously in terms of politicisation of the social is now perceived in terms of institutional reform" (Talshir 2003: 174).

\section{Conclusion}

Finally, why do Green parties emerge? As we have demonstrated, the post-materialist factor, once conceived as a decisive variable, might constitute a sociological characteristic of the Green electorate more than an explanatory variable of Green party emergence. Following our argumentation and the lights shed by the comparative perspective, we can defend that the emergence of Green parties is fundamentally related with institutional and strategic factors. In terms of financing, Die Grünen have largely benefited from public funds while the British Greens have been confined within an associative logic, being dependent on membership fees and consequently incapable to present candidates and develop a national political strategy. Moreover, the British electoral system has drastically restrained the possibilities of emergence of the Greens, while the German system has encouraged the development of a multi-party system and the equitable representation of political forces. The institutional stability of a "weak state with strong power" in Great-Britain has reinforced the centralisation of the decision-making process at the governmental level, creating an unfavourable structure of political opportunities for the Greens and stimulating in response its centrifugal tendencies. On the other hand, the structure with multiple levels of governance and the "cooperative federalism" of the German system have tended to multiply the possibilities of entry for a new party, the party system in itself enabling the creation of party coalitions. In the end, from a strategic viewpoint, the British Greens "cultural revolution" has largely been a failure while Die Grünen's willingness to incarnate an electoral alternative has been much more successful. Intransigent extra-parliamentary strategy, control of the leadership and internal democracy have been political decisions with a high costs for the British Greens, that of non-emergence. Nevertheless, these choices such as the radicalisation of the party after the victory of the fundamentalists can be better understood in the light of the constraints of the institutional system in itself. Die Grünen have been successful in institutionalizing a citizen movement into a reformist political party, enhancing a strategy of compromises and electoral coalition-building combined with a realist use of power in search of the median centre-left voter, converting gradually the German Greens to classical political liberalism.

\section{References}

Armingeon, K 2002, "The effects of negotiation democracy: A comparative analysis", European Journal of Political Research, vol. 41, no. 1, pp. 81-105.

Bennie, L G, Franklin, M N \& Rüdig, W 1995, "Green Dimensions: The Ideology of the British Greens", in Rüdig, W (ed.), Green Politics Three, Edinburgh University Press, Edinburgh, pp. 217-39.

Bogdanor, V 1984, "Financing Political Parties in Britain", in Bogdanor, E (ed.), Parties and Democracy in Britain and America, Praeger, New York. 
Bündis 90/Die Grünen 2002, The Future is Green, Alliance 90/The Greens: Program and Principles, viewed 26 December 2006, <www.gruene.de/grundsatzprogramm-english.pdf>.

Burgi, N 1992, "État faible, pouvoir fort: I'exemple de la Grande-Bretagne", Revue Française de Science Politique, vol. 42, no. 3, pp. 402-16.

Cox, G 1997, Making Votes Count: Strategic Coordination in the World's Electoral Systems, Cambridge University Press, Cambridge.

Coxall, W 2001, Pressure Groups in British Politics, Longman, Harlow.

Crewe, I 1993, "Parties and Electors", in Budge, I \& McKay, D (eds.), The Developing British Political System: The 1990s", Longman, London, pp. 83-111.

De Winter, L \& Tursan, H 1998, Regionalist Parties in Western Europe, Routledge, London.

Douglas, M \& Wildasky, A 1983, Risk and Culture. An Essay on the Selection of Technological and Environmental Dangers, University of California Press, Berkeley.

Dunleavy, P, Margetts, H \& Weir, S 1994, "The 1992 election and the legitimacy of British Democracy", in Denver, D, Norris, P, Broughton, D \& Rallings, C (eds.), British Elections and Parties Yearbook 1993, Harvester, Hemel Hempstead, pp. 177-92.

Eurobarometer 64.2 2006, L'Opinion Publique dans I'Union Européenne, European Commission, General Secretary for Communication, viewed 15 December 2006, $<$ http://europa.eu.int/comm/public_opinion/index_fr.htm>.

Faucher, F 1999, Les Habits Verts de la Politique, Presses de Sciences-po, Paris.

2000, "Le Système Électoral Britannique", in Delwit, P \& De Waele, J M, Le Mode de Scrutin fait-il l'élection ?, Université Libre de Bruxelles, Bruxelles pp. 52-67.

Grossman, E \& Saurugger, S 2006, Les groupes d'intérêt. Action collective et stratégies de représentation, Armand Colin, Paris.

Harmel, R \& Sväsand, J D 1997, "Formation and Success of New Parties", International Political Science Review, vol. 6, no. 4, pp. 501-23.

Heywood, A 1994, "Britain's Dominant Party System", in Robins, L, Blackmore, H \& Pyper, R (eds.), Britain's Changing Party System, Leicester University Press, London, pp. 10-25.

Hug, S 2001, Altering Party System: Strategic Behaviour and the Emergence of New Political Parties in Western Democracies, University of Michigan Press, Ann Arbor.

Icke, D 1990, It doesn't have to be like this. Green Politics Explained, Green Print, London.

Ignazi, P 1992, "The Silent Counter-Revolution: Hypotheses on the Emergence of Extreme Right-Wing Parties in Europe", European Journal of Political Research, vol. 22, no. 1, pp. 3-34.

Inglehart, R 1991, El cambio cultural en las sociedades industriales avanzadas, Centro de Investigaciones Sociológicas, Madrid. 
Kalyvas, S N 1996, The Rise of Christian Democracy in Europe, Cornell University Press, Ithaca.

Katz, R S \& Mair, P 1994, "The Evolution of Party Organization in Europe: The Three Faces of Party Organization", in Crotty, W (ed.), Parties in an Age of Change, American Review of Politics, vol. 14, no. 4, pp. 593-617.

Kitschelt, H 1986, "Political opportunity structures and political protest: anti-nuclear movements in four democracies", British Journal of Political Science, vol. 16, no. 1, pp. 57-85.

1989, The Logics of Party Formation, Cornell University Press, Ithaca.

1998, The Radical Right in Western Europe: A Comparative Analysis, University of Michigan Press, Ann Arbor.

Lijphart, A 1999, Patterns of Democracy: Government Forms and Performance in Thirty-Six Countries, Yale University Press, New Haven.

Lipietz, A 1993, Vert espérance. L'avenir de l'écologie politique, La Découverte, Paris.

Mair, P 1995, "Political Parties, Popular Legitimacy and Public Privilege", West European Politics, vol. 18 , no. 1 , pp. $40-57$.

Manin, B 1995, Principes du Gouvernement Représentatif, Calmann-Lévy, Paris.

Markovits, S \& Gorski, P S 1993, The German Left: Red, Green and Beyond, Oxford University Press, New York.

Martin, P 2000, "Les Principaux Modes de Scrutin en Europe", in Delwit, P \& De Waele, J M, Le Mode de Scrutin fait-il l'élection ?, Université Libre de Bruxelles, Bruxelles, pp. 39-51

Olivo, C 2001, Creating a Democratic Civil Society in Eastern Germany. The Case of the Citizen Movements and Alliance 90, Palgrave, New York.

Panebianco, A 1988, Political Parties: Organization and Power, Cambridge University Press, Cambridge.

Papadakis, E 1984, The Green Movement in West Germany, Croom Helm, London \& Canberra.

Poguntke, T 1993, Alternative Politics, The German Green Party, Edinburgh University Press, Edinburgh.

1994, "Parties in a Legalistic Culture: The Case of Germany", in Katz, R S \& Mair, P (eds.), How Parties Organize. Change and Adaptation in Party Organizations in Western Democracies, Sage, London, pp. 185-216.

Poguntke, T \& Bernhard, B 1992, "Germany", in Katz, R S, Mair, P (eds.), Party Organizations: A Data Handbook on Party Organizations in Western Democracies, 1960-90, Sage, London, pp. 31788.

Rosenstone, S J, Roy, L B \& Lazarus, E H 1984, Third Parties in America, Princeton University Press, Princeton. 
Rucht, D 1990, "The Strategies and Action Repertoires of New Movements", in Dalton, R \& Kuechler, M, Challenging the Political Order. New Social Movements in Western Democracies, Polity Press, Oxford, pp. 156-75.

Rüdig, W 1995, "Green Dimensions, The Ideology of the British Greens", in Rüdig, W (ed.), Green Politics Three, Edinburgh University Press, Edinburgh, pp. 217-39.

Sartori, G 2005[1976], Parties and Party Systems. A Framework for Analysis, Cambridge University Press, Cambridge.

Saward, P M 1993, “Green Democracy?", in Dobson, A \& Lucardie, P, The Politics of Nature. Exploration in Green Political Theory, Routledge, London, pp. 24-46.

Schmitt, H \& Holmberg, S 1995, "Political parties in Decline", in Klingemann, H D \& Fuhs, D (eds.), Citizens and the State, Oxford University Press, Oxford, pp. 95-132.

Storm, K \& Müller, W C 1999, "Political Parties and Hard Choices", in Storm, K \& Müller, W C, Policy, Office or Voter, Cambridge University Press, Cambridge.

Talshir, G 1998, "Modular Ideology: the implications of Green Theory for a reconceptualization of 'ideology'”, Journal of Political Ideologies, vol. 3, no. 2, pp. 169-92.

2003, "A threefold ideological analysis of Die Grünen: from ecologized socialism to political liberalism?", Journal of Political Ideologies, vol. 8, no. 2, pp. 157-184.

Tarrow, S 1995, "States and opportunities: the political structuring of social movements", in McAdam, D, McCarthy, J \& Zald, M (eds.), Comparative Perspectives on Social Movements: Opportunities, Mobilizing Structures and Framing, Cambridge University Press, Cambridge, pp. 41-62.

Tavits, M 2006, "Party System Change: Testing a Model of New Party Entry", Party Politics, vol. 12, no. 1, pp. 99-119.

Wachendorfer-Schmidt, U 2000, "Collaborative Federalism in Germany. Keeping the System in the Eye of the Storm", in Wachendorfer-Schmidt, U (ed.), Federalism and Political Performance, Routledge, London \& New York, pp. 81-111.

Waechter, A 1990, Dessine-moi une Planète, Albin Michel, Paris.

Webb, P \& Fisher, J 1999, "The Changing British Party System: Two-party Equilibrium or the Emergence of Moderate Pluralism?", in Broughton, D \& Donovan, M (ed.), Changing Party Systems in Western Europe, Pinter, London \& New York, pp. 14-29. 